\title{
ANALISIS RISIKO NATION BRANDING DALAM PENYELENGGARAAN KAWASAN EKONOMI KHUSUS MANDALIKA
}

\section{RISK ANALYSIS OF NATION BRANDING IN MANDALIKA SPECIAL ECONOMIC ZONE MANAGEMENT}

\author{
Sonny T. Danaparamita ${ }^{1}$ \\ ${ }^{1}$ Faculty of Law University of Jember, Jember, Indonesia \\ E-mail: always_sonny@yahoo.com
}

\begin{abstract}
ABSTRAK
Penelitian ini merupakan penelitian yuridis normative yang menganalisa risiko Nation branding terhadap Kawasan Ekonomi Khusus didaerah Mandalika. Dalam penelitian ini teori yang digunakan adalah theory hukum murni Hans Kelsen dimana mempunyai dua fungsi, yaitu: pertama, di satu segi berfungsi sebagai epistemologi dan metodologi yang oleh para sarjana hukum dijadikan landasan dalam ilmu hukum (rechtsdogmatik); dan yang kedua, juga berfungsi kritis dengan posisi bersebrangan terhadap ilmu hukum konvensional. Theory tersebut untuk menjawab masalah penelitian yaitu Pertama, terkait risiko Nation Branding pada Kawasan Ekonomi Khusus dan Kedua, realitas keadilan sosial pada Kawasan Ekonomi Khusus dengan mengambil locus penelitian di kawasan ekonomi khusus Mandalika. Temuan dalam penelitian ini diantaranya bahwa Secara umum hukum investasi sebagai kerangka nation branding dalam penyelenggaraan kawasan ekonomi khusus di mandalika, ditandai dengan inkonsistensi penerapan hukum, yang cenderung melenyapkan rasa keadilan kolektif masyarakat Indonesia.

Kata Kunci: Kawasan Ekonomi Khusus, Investasi, Mandalika..
\end{abstract}

\begin{abstract}
This research is a normative juridical research that analyzes the risk of branding in the administration of economic zones. Especially in the mandalika area, in this study the theory used is the pure legal theory of Hans Kelsen which has two functions, namely: first, on the one hand it functions as an epistemology and methodology which legal scholars use as the basis for legal science (rechtsdogmatic); and secondly, it also functions critically with the opposite position to conventional legal science. The theory is to answer research problems, namely First, related to the risk of Nation Branding in the Special Economic Zone and Second, the reality of social justice in the Special Economic Zone by taking the research locus in the Special Economic Zone of Mandalika. The findings in this study include that in general investment law as a nation branding framework in the administration of special economic zones in Mandalika, is characterized by inconsistencies in the application of law, which tends to eliminate the collective sense of justice of the Indonesian people.
\end{abstract}

Keywords: Special Economic Zone, Investment, Mandalika. 


\section{PENDAHULUAN}

Penyelenggaraan penanaman modal untuk mempercepat pengembangan ekonomi di wilayah tertentu yang bersifat strategis bagi pengembangan ekonomi nasional, menjaga keseimbangan dan kemajuan suatu daerah dalam kesatuan ekonomi nasional merupakan suatu kebijakan yang dipandang sebagai suatu terobosan baru untuk peningkatan investasi di Indonesia. Regulasi tersebut adalah amanat dari Undang-undang Nomor 25 Tahun 2007 tentang Penanaman Modal yakni Undang-undang Nomor 39 Tahun 2009 tentang Kawasan Ekonomi Khusus atau disingkat UU KEK.

KEK sebagai bagian dari penanaman modal sebagaimana telah diterbitkan peraturan khusus tentang kawasan ekonomi khusus yakni Undang-undang Nomor 39 Tahun 2009 Tentang Kawasan Ekonomi Khusus tidak mengatur secara rinci kriteria yang harus dipenuhi seperti dalam undang-undang penanaman modal tetapi untuk fasilitas tertentu diatur kriteria sebagai syarat untuk mendapatkan fasilitas.

KEK Mandalika di tetapkan sebagai Kawasan Ekonomi Khusus Pariwisata berdasarkan pada Peraturan Pemerintah Nomor 52 Tahun 2014 tentang Kawasan Ekonomi Khusus. Dengan luas area sebesar 1.035,67 Ha dan langsung berhadapan dengan indahnya
Samudera Hindia, KEK Mandalika diharapkan dapat mempercepat tumbuhnya sektor pariwisata baru di Provinsi Nusa Tenggara Barat yang membawa dampak ekonomi yang positif bagi masyarakat.

Melihat potensi dan keuntungan yang ada, PT Pengembangan Pariwisata Indonesia (Persero) yang telah berhasil membangun Nusa Dua Bali mengusulkan pembentukan KEK Mandalika. Gagasan untuk menumbuhkan pariwisata berwawasan lingkungan dengan pembangunan obyek wisata dan tempat liburan yang selalu ditata dengan mengutamakan kelestarian nilai dan kearifan lokal yang hidup di masyarakat. (https://kek.go.id/kawasan/Mandalika)

KEK Mandalika merupakan KEK yang paling diminati oleh para investor saat ini dan diupayakan untuk menjadi destinasi wisata kelas dunia. KEK Mandalika diproyeksikan dapat menarik dana investasi sebesar Rp.40T dan mengasimilasi tenaga kerja sebanyak 587.000 hingga tahun 2025. Pemerintah memberikan jalan yang mempermudah investor dalam pelayanan keimigrasian, perizinan, kepabeanan dan lain-lain melalui regulasi yang dibangun, sehingga dengan demikian dari sisi fiskal investor dapat memanajemen segala biaya yang akan dikeluarkan seminimal mungkin dalam kegiatan penanaman modal. 
Oleh sebab itu, peran pemerintah dibutuhkan sebagai forum untuk menetapkan hukum atau rule of the game dan sebagai wasit yang menafsirkan dan menegakkan (enforce) dari rule of the game yang sudah ditetapkan (Bismar, 2011). Pemerintah yang dimaksud disini adalah pemerintah yang bersinergi antara pemerintah pusat dan daerah dalam membangun dan mengembangkan KEK.

Oleh karena itu suatu penelitian Analisis Risiko Nation Branding Dalam Penyelenggaraan Kawasan Ekonomi Khusus Mandalika Untuk mengetahui pertimbangan serta risiko dari Undang-undang Nomor 25 Tahun 2007 Tentang Penanaman Modal dan Undang-undang Nomor 39 Tahun 2009 Tentang Kawasan Ekonomi Khusus sebagai Nation Branding.

Penelitian ini untuk mengetahui dan menganalisis peran pemerintah pusat dan daerah dalam rangka pemberian fasilitas kepada investor di kawasan Ekonomi Khusus (KEK) berdasarkan Undang-undang Nomor 25 Tahun 2007 Tentang Penanaman Modal dan Undangundang Nomor 39 Tahun 2009 Tentang Kawasan Ekonomi Khusus.

\section{METODE PENELITIAN}

Penelitian ini menggunakan penelitian yuridis, dan hukum normatif. Bahan hukum sekunder berupa buku, jurnal, dan karya tulis ilmiah hukum. Bahan non hukum berupa buku non hukum dan informasi yang diakses melalui internet.

\section{HASIL PENELITIAN DAN PEMBAHASAN}

\section{A. Manajemen Risiko Hukum}

Risiko dapat di definisikan sebagai kemungkinan kerugian atau hasil yang tidak menguntungkan terkait dengan tindakan. Ketidakpastian tidak mengetahui apa yang akan terjadi di masa depan. Semakin besar ketidakpastian yang timbul maka semakin besar pula risikonya (Laurence Crane dkk, 2001). Menurut Kamus Bahasa Indonesia, risiko adalah akibat yang kurang menyenangkan (merugikan, membahayakan) dari suatu perbuatan atau tindakan. Sementar itu, menurut Black's Law Dictionary - Eight Edition, risiko didefinisikan sebagai berikut (Bryan A. Garner, 2004): Ketidakpastian akibat, terjadi, atau kehilangan, kemungkinan cedera, atau kerugian: terutama, keberadaan dan luasnya kemungkinan kerusakan.

Dalam ajaran hukum perdata di Indonesia, Risiko (resicoleer) adalah keadaan seorang berkewajiban untuk memikul kerugian jika ada suatu kejadian di luar kesalahan salah satu pihak. Dengan bahasa sederhana risiko adalah kerugian yang ditimbulkan di luar kesalahan salah satu pihak yang menimpa 
benda yang menjadi objek perjanjian. Ajaran ini timbul oleh karena adanya keadaan memaksa (overmacht). Subekti memberikan suatu definisi, risiko yaitu kewajiban untuk memikul kerugian yang disebabkan oleh suatu peristiwa yang terjadi diluar kesalahan salah satu pihak, yang menimpa barang yang menjadi objek perjanjian

((http://www.negarahukum.com/hukum/ri siko.html).

Perlu dipahami juga, mengingat risiko didefinisikan sebagai kemungkinan kerugian atau hasil yang tidak menguntungkan terkait dengan tindakan, maka yang harus dilakukan oleh manusia adalah menjaga agar risiko tersebut tidak terjadi. Masalah adalah kejadian yang sudah terjadi sedangkan risiko adalah kejadian yang belum terjadi yang masih mengandung kemungkinan-kemungkinan, artinya bisa saja terjadi bisa juga tidak. Selain itu ada kejadian-kejadian yang tidak memiliki unsur kerugian namun yang ada hanya unsur keuntungan sehingga tidak bisa dianggap risiko karena risiko didefinisikan sebagai kemungkinan kejadian yang merugikan. Secara umum risiko dapat dikelompokkan sebagai berikut:

1. Risiko murni (pure risk), adalah risiko di mana kemungkinan kerugian ada, tetapi kemungkinan keuntungan tidak ada (yang ada hanya kerugian). Contoh: risiko kecelakaan, kebakaran, banjir dan semacamnya (risiko-risiko yang bergerak pada satu arah saja, yaitu arah kerugian). Risiko murni sendiri dapat dikelompokkan pada tiga kriteria risiko, yaitu (Nur Hidayat, 2015):

1. Risiko aset fisik; merupakan risiko yang berakibat timbulnya kerugian pada aset fisik suatu perusahaan. Contoh kebakaran, banjir, gempa, gunung meletus, dan lain-lain.

2. Risiko karyawan; merupakan risiko karena yang dialami oleh karyawan yang bekerja di perusahaan tersebut. Contoh: kecelakaan kerja sehingga aktifitas perusahaan terganggu.

3. Risiko legal; merupakan risiko dalam bidang kontrak yang mengecewakan atau kontrak tidak berjalan sesuai dengn rencana. Risiko ini akibat kelemahan masalah hukum, mulai dari tuntutan hukum, tidak adanya kerangka hukum dan kelemahan perjanjian. Contoh: perselisihan dengan perusahaan lain sehingga 
adanya persoalan seperti gugatan hukum dan ganti rugi.

2. Risiko spekulatif (speculative risk), yaitu risiko di mana kita mengharapkan terjadinya kerugian dan juga keuntungan. Kemungkinan untuk usaha kita mengalami kerugian ada, akan tetapi terdapat jug kemungkinan untuk untung. Risiko tersebut biasanya berkaitan dengan risiko usaha. Risiko spekulatif dapat dikelompokkan sebagai berikut:

a. Risiko pasar; merupakan risiko yang timbul karena adanya pergerakan variabel pasar yang bervariasi, seperti akibat suku bunga, nilai tukar dan komoditas.

b. Risiko

kredit/investasi; merupakan risiko yang terjadi karena counter party(debitur) gagal memenuhi kewajibannya kepada perusahaan. Contoh: kredit macet, persentase piutang yang semakin meningkat.

c. Risiko likuiditas; merupakan risiko karena ketidakmampuan memenuhi kebutuhan kas/ketidakmampuan dalam menempatkan kewajiban (liability). Contoh: kemampuan kas yang menurun sehingga pengusaha tidak lagi mampu membayar utang secara tepat, akhirnya menyebabkan perusahaan harus menjual aset yang dimilikinya.

d. Risiko operasional; merupakan risiko yang disebabkan pada kegiatan operasional yang tidak berjalan dengan lancar. Contoh: terjadinya kesalahan dalam perhitungan pajak yang mengakibatkan timbulnya sanksi, kesalahan terjadi karena karyawan bagian pajak yang tidak ter-update pengetahuan perpajakannya.

e. Risiko strategi; risiko yang timbul akibat lemahnya pembentukan dan penerapan stategi perusahaan, lemahnya pengambilan keputusan dalam dunia usaha atau kesenjangan reaksi dalam menghadapi perubahan. Risiko ini dikelola oleh direksi dan memerlukan perencanaan stategi yang mendalam.

PT Persero Indonesia Tourism Development Corporation (ITDC) selaku BUMN yang mendapatkan amanat untuk menjadi pengembang dan pengelola. Memiliki gagasan untuk menumbuhkan pariwisata yang ramah lingkungan dengan peningkatan obyek wisata dan daya tarik 
wisatawan yang berorientasi kepada kelestarian nilai-nilai budaya lokal. Sebagai BUMN maka ada aturan yang mengatur mengenai manajemen risiko, penerapan aturan manajemen risiko bagi BUMN diawali dengan adanya Peraturan Menteri (Permen) BUMN Nomor: PER01/MBU/2011 tentang Penerapan Tata Kelola Perusahaan yang Baik (Good Corporate Governance/GCG) pada Badan Usaha Milik Negara. Di dalam ketentuan Permen BUMN ini Pasal 2 ayat (1) mewajibkan BUMN untuk menerapkan GCG secara konsisten dan berkelanjutan.

BUMN merupakan perusahaan negara yang pada satu sisi terikat pada ketentuan-ketentuan kepemerintahan dibidang hukum publik, disisi lain terikat pada ketentuan-ketentuan hukum privat. Hal ini disebabkan modal BUMN merupakan berasal dari kekayaan negara yang dipisahkan. Pemisahan kekayaan negara pada BUMN harus dipandang bahwa negara memisahkan kekayaan sebagai modal pada perseroan, hak dan kewajiban terhadap dana tersebut bertransformasi menjadi kepemilikan saham sebagai konsekuensi dari dibentuknya subjek hukum yang juga memiliki hak dan kewajiban tersendiri (Merdiansa Paputungan, 2013).
BUMN Memiliki dua fungsi unik sekaligus, yaitu fungsi ekonomi (privat sector) dan fungsi social (public service). BUMN diharapkan dapat memberikan kontribusi yang optimal terhadap keuangan negara. Maka tentu saja akan berakibat pada multi fungsi tersebut, yang sering menyebabkan manajemen BUMN tidak dapat menjalankan dua fungsinya sekaligus. Tujuan didirikannya BUMN, antara lain ( Davas, 1990):

1. Melaksanakan ideologi tertentu, di mana seluruh sarana atau alat produksi dianggap sebagai milik masyarakat.

2. Melindungi masyarakat selaku konsumen terhadap adanya monopoli alamiah.

3. Mengambil alih perusahaan asing.

4. Menciptakan lapangan kerja bagi masyarakat

5. Memenuhi kebutuhan masyarakat yang tidak dapat dipenuhi oleh swasta, karena memerlukan modal yang relatif besar.

6. Mendorong laju pertumbuhan ekonomi, sehingga dapat mendorong laju pembangunan.

7. Menambah penerimaan bagi negara/daerah).

Analisis Risiko spekulatif pada Kawasan Ekonomi Khusus Mandalika dapat dikelompokkan sebagai berikut: 
a. Risiko pasar; dalam rangka pemulihan ekonomi nasional Bank Indonesia telah menurunkan suku bunga terendah ke angka 3,5\%. Bank Indonesia juga melakukan upaya ketersediaan APBN dengan cara burden sharingsharing melalui pembelian surat utang negara yang mencapai 65 triliun.

b. Risiko kredit/investasi; risiko persentase piutang meningkat diakibatkan beban ekonomi dan pandemi menjadi kendala yang unik dan tidak dapat dihindari sehingga dalam kebijakan investasi ada .

c. Risiko likuiditas; perihal risiko ini BUMN memenuhi kebutuhan kas/ketidakmampuan dalam menempatkan kewajiban (liability). Melalui kebijakan pemerintah Penyertaan Modal Negara. Penyertaan Modal Negara (PMN) berdasarkan PP No. 44 Tahun 2005 tentang Tata Cara Penyertaan dan Penatausahaan Modal Negara pada Badan Usaha Milik Negara dan Perseroan Terbatas memiliki definisi yaitu pemisahan kekayaan negara dari Anggaran Pendapatan dan Belanja Negara atau penetapan cadangan perusahan atau sumber lain yang dijadikan sebagai modal BUMN dan/atau Perseroan
Terbatas lainnya, dan dikelola secara korporasi. Komitmen pemberian PMN dilakukan dengan tujuan utamanya untuk meningkatkan kapasitas kemampuan usaha dan memperbaiki struktur permodalan.

d. Risiko operasional; merupakan risiko yang disebabkan pada kegiatan operasional yang tidak berjalan dengan lancar. untuk menghadapi pandemi maka kegiatan operasional pembangunan juga memberlakukan PSBB (Pembatasan Sosial Berskala Besar). Dengan diberlakukannya PSBB, tentu berdampak langsung pada biaya kegiatan operasional. Dengan kebijakan tambahan kebijakan tersebut tentu menyebabkan bertambahnya beban biaya yang harus ditanggung sebagai konsekuensi dari proses pembangunan yang terus dilanjutkan sekalipun dalam masa pandemi covid19

e. Risiko strategi; risiko yang timbul akibat lemahnya pembentukan dan penerapan stategi perusahaan, lemahnya pengambilan keputusan dalam dunia usaha atau kesenjangan reaksi dalam menghadapi perubahan. Risiko ini dikelola pada level direksi dan memerlukan perencanaan stategi. Kedepan tentu pengembangan industri 
yang melibatkan banyak manusia pasti akan menyebabkan banyak kemungkinan kerugian baik secara financial maupun secara progres bisnis.

Peran Perusahaan negara / BUMN dalam ketenagakerjaan Salah satu peran BUMN yang dapat dirasakan langsung oleh masyarakat adalah peran BUMN dalam menciptakan lapangan kerja serta mendukung pengembangan UMKM. Keadaan yang harus dipahami ialah tujuan utama dari keberadaan BUMN, yang tidak semata-mata hanya mencari keuntungan yang besar, akan tetapi memiliki peran utama yakni pengabdian kepada rakyat melalu kemampuan sesuai bidang usaha yang dijalankannya. Oleh karena itu kondisi BUMN yang kadangkadang harus merugi karena mengemban misi-misi tertentu dari pemerintah untuk kesejahteraan rakyat merupakan pilihan yang tidak terelakkan namun demikian hal ini sering terabaikan oleh beberapa BUMN.

Hari ini, BUMN dihadapkan pada suatu pasar yang kompetitif dan global dengan intensitas persaingan yang semakin ketat. Dengan bermodalkan keuangan yang cukup saja, belum memberikan jaminan bahwa BUMN akan mampu bertahan hidup dan bersaing di pasar global. BUMN harus mampu menjaring dan melayani konsumen dengan standart kualitas yang lebih baik lagi. Potensi pasar tidak hanya terbatas di pasar dalam negeri, tetapi juga di pasar luar negeri. Namun sebaliknya, pesaing dari luar negeri juga akan memperebutkan pasar yang ada di dalam negeri. Untuk mengantisipasi peluang dan ancaman tersebut, BUMN harus mempersiapkan diri dengan fokus utama adalah analisis risiko kedepan dan peningkatan kualitas produk yang ingin dipasarkan.

Disinilah peran strategis BUMN dalam menganalisis risiko hukum dapat segera ditingkatkan. BUMN dapat memanfaatkan teknologi dan sumber daya manusia yang handal untuk menciptakan produk yang berkualitas baik. Dengan teknologi tersebut, BUMN harus mampu menciptakan proses bisnis internal yang efisien agar dapat menghasilkan produk dengan harga yang bersaing. Dan yang tidak kalah penting, para karyawan BUMN harus memiliki motivasi yang kuat untuk selalu meningkatkan kemampuan pada dirinya agar sejalan dengan perkembangan teknologi yang digunakan.

\section{B. Realitas Keadilan Sosial pada Kawasan Ekonomi Khusus Mandalika}


Sebuah negara menurut Agustine merupkan komunitas hukum, tidak akan ada tanpa keadilan. "dimana tidak ada keadilan sejati, disitu tidak ada hukum". Karena apa yang diperbuat oleh hukum, diperbuat pula oleh keadilan, dan apa yang dilakukan secara tidak adil, berarti ia dilakukan secara melanggar hukum. Dia menjelaskan bahwa keadilan diasumsikan sebagai kriteria tatanan norma yang disebut "hukum", maka tatanan pemaksa kapitalis barat bukanlah hukum, dari sudut pandang cita-cita keadilan komunis, demikian sebaliknya. Sebuah konsep hukum dengan konsekuensi semacam itu tidak bisa diterima oleh hukum positivis.

Kesenjangan ekonomi merupakan kenyataan yang kian hari berkembang luas dalam dinamika kehidupan bermasyarakat. Ketimpangan dan kesenjangan itu juga terjadi di Indonesia yang dikenal sangat majemuk sehingga faktor-faktor kemajemukan itu menambah masalah dan menyebabkan potensi konflik sosial, disharmonisasi, dan disintegrasi sosial yang semakin membahayakan kerukunan hidup bersama.

Mengenai doktrin kedaulatan rakyat, dapat dikemukakan adanya pendapat yang berbeda atas pemaknaannya oleh Bung
Karno dan Soepomo. Menurut Soekarno, kedaulatan rakyat itu bukanlah kedaulatan rakyat sebagai individu (Person), tetapi kedaulatan rakyat dalam arti kolektif (Jimly Asshiddiqie, 1994). Namun pandangan kolektivis tentang kedaulatan rakyat seperti demikian dewasa ini tidak lagi dianut oleh Undang-Undang Dasar tahun 1945. Sejak perubahan II UUD 1945 pada tahun 2000, ketentuan tentang hak asasi manusia sudah diadopsi lengkap dalam UUD 1945, mulai dari Pasal 28A sampai dengan Pasal 28J. Hampir semua materi hak asasi manusia yang terdapat dalam instrumen HAM Internasional diadopsi menjadi materi UUD 1954.

Dengan demikian, kedaulatan rakyat yang dimaksud sila keempat dan dijabarkan dalam ketentuan Pasal 1 Ayat (1) UUD 1945 adalah kedaulatan rakyat, baik sebagai pribadi-pribadi maupun sebagai kolektivitas seluruh rakyat Indonesia. Dalam prinsip demokrasi Pancasila, ada kebebasan yang luas dan terbuka, tetapi dipimpin oleh hikmat kebijaksanaan dalam permusyawaratan dan perwakilan. Kemerdekaan kolektif sebagai bangsa tidak terpisah dengan kebebasan individu bagi setiap rakyat indonesia. Tidak ada kemerdekaan tanpa kebebasan dan tidak ada gunanya hidup 
bebas tetapi terkungkung dalam penjajahan kolektif oleh bangsa lain.

Beberapa pengaturan terkait dengan fasilitas bagi investor yang menanamkan modalnya di KEK berdasarkan UU KEK yang tidak sinkron dengan peraturan yang lain yang terkait. Pertama, fasilitas $\mathrm{PPh}$ dalam UU KEK diberikan kepada setiap wajib pajak yang melakukan kegiatan usaha di KEK.Wajib pajak di KEK dapat berupa orang perseorangan, berbadan hukum dan/atau tidak berbadan hukum.Fasilitas $\mathrm{PPh}$ tersebut diberikan sesuai dengan ketentuan peraturan perundang-undangan

Realisasi anggaran pembangunan infrastruktur strategi Pariwisata Nasional (KSPN) Mandalika di lombok, mencapai Rp 447 miliar. Dimana alokasi anggaran untuk pembangunan sirkuit tersebut sebesar Rp 1.7 triliun. Anggaran tersebut di gunkan untuk pembangunan infrastruktur sumber saya air (SDA) sebesar Rp 154 miliar, jalan dan jembatan sebesar Rp 1,45 triliun, pemukiman 223 miliar, dan perumahan Rp 132 miliar. Sedangkan total serapan pekerja di KEK Mandalika tercatat mencapi 1.100 orang. Secara rinci, 100 diantaranya bertugas sebagai penjaga keamanan, 50 orang tukang kebun, 50 orang cleaning servis, 300 orang sebagai pekerja proyek, 50 orang sebagai petugas perkantoran, 50 orang sebagai supplier, dan 500 orang bekerja disektor UMKM. PT Indonesia Tourism Development Corporation (PT ITDC) harus mendatangkan aspal khusus dari Inggris untuk lintasan Moto GP di sirkuit KEK Mandalika. Hal tersebut demi dilakukan demi terpenuhinya standart kualitas bangunan yang telah ditetapkan oleh Federasi Motor Internasional (FIM) yang menetapkan aturan dan tertuang dalam dokumen bertajuk Standards for Circuits. Diperkirkan ketika Covid-19 berakhir jumlah penonton di sirkuit Mandalika bisa mencapai 160 ribu orang.

Belajar dari Brazil yang memiliki suatu nilai yang dapat ditonjolkan dalam momen olimpiade yang diadakan di kota Rio. Sebagai negara dengan budaya yang beragam, Brazil melakukan branding terhadap budaya mereka agar semakin dikenal oleh dunia internasional. Hal tersebut menjadi alasan mengapa olimpiade merupakan alat bagi kepentingan negara mereka. Brazil memiliki banyak faktor pendukung sehingga mereka perlu melakukan diplomasi budaya dalam hal ini nation branding untuk meningkatkan bargaining position negara terutama di wilayah benua Amerika dan internasional. 
Ditambah lagi, Brazil juga perlu memperbaiki citra buruk mereka yang dapat mengancam kondisi domestik mereka.

Bagaimana London kedatangan wisatawan asing setelah terpilih menjadi tuan rumah Olimpiade pada tahun 2012, terhitung hampir 10 juta orang lebih yang datang dari luar negeri karena reputasi mereka sebagai tuan rumah Olimpiade membantu hal tersebut. Jika mengacu pada London, maka situasi serupa bisa dialami oleh Brazil dimana mereka memiliki reputasi yang sama yaitu tuan rumah Olimpiade dan hal ini pasti akan memancing wisatawan asing untuk berkunjung karena dampak yang dihasilkan oleh promosi dan branding yang dilakukan Brazil dalam mempromosikan Olimpiade ini ke seluruh dunia. Bukan hanya di Kota Rio de Janeiro yang sebagai pusat kedatangan wisatawan asing untuk menikmati Olimpiade, melainkan tersebar juga ke beberapa kota lainnya di Brazil.

Akan tetapi ini tidak terjadi, krisis ekonomi yang di ikuti dengan konflik sosial yang terus berkelanjutan sebagai akibat beban pembangunan yang harus ditanggung kemudian untuk menyelenggarakan olimpiade tersebut menyebabkan Brasil semakin terpuruk dengan ekonominya, semua ini karena kegagalan dalam melihat risiko-risiko dari bias keterwakilan (representative bias). Dalam mazhab ekonomi yang relatif baru yang disebut dengan keuangan perilaku, berpendapat bahwa literatur yang sangat banyak tentang stategi-strategi ekonomi telah melewatkan hal besar dan lebih penting yakni keadilan dan keadaban. Disana juga dijelaskan bahwa orang-orang cenderung menyakini bahwa sempel kecil mewakili populasi yang besar dan menyimpulkan sebuah pola terlalu cepat (Zvi Bodie, Alex Kane, and Alan J. Marcus, 2019).

Berkenaan dengan keadilan sosial Kelsen menyatakan, seandainya memang mungkin untuk membuktikan bahwa keadaan ekonomi rakyat dapat diperbaiki secara esensial oleh apa yang dinamakan ekonomi terencana (planned economy), bahwa keamanan sosial (social security) dijamin untuk setiap orang dengan ukuruan yang setara, akan tetapi pengorganisasian ke arah itu hanya mungkin jika semua kebebasan individu sama sekali dihapus.

Menurutnya, apakah ekonomi terencana lebih baik dipilih dari ekonomi pasar bebas tergantung keputusan kita untuk memilih di antara nilai-nilai kebebasan individu dengan keamanan 
sosial. Konsistensi dan budaya estafet yang perlu dipraktikkan secara nyata, merupakan proses pembangunan yang menuju keadilan sosial bagi seluruh rakyat Indonesia ialah suatu kontinuitas, yaitu proses yang berkesinambungan dan berkelanjutan. Semua kebijakan hendaknya mencerminkan kesadaran kolektif yang berporos untuk kemajuan peradaban bangsa Indonesia dalam jangka panjang, dan secara sinergis harus bergerak bersama-sama dan digerakkan untuk mendorong peningkatan kuantitas dan kualitas kesejahteraan yang merata dan berkeadilan dengan ukuran yang pasti, bahwa kesenjangan sosial tidak boleh melampaui standar-standar ukuran yang berlaku universal dalam kehidupan umat manusia

\section{SIMPULAN}

Secara umum, hukum investasi adalah kerangka berfikir untuk mewujudkan nation branding dengan penyelenggaraan kawasan ekonomi khusus di Mandalika, ditandai dengan inkonsistensi penerapan hukum, yang cenderung melenyapkan rasa keadilan kolektif masyarakat Indonesia.

Efektivitas dari peran negara dan masyarakat menjadi faktor kunci sekaligus penentu. Karena itu, pembangunan kawasan ekonomi khusus tidak lain merupakan proses dari, oleh, dan untuk manusia Indonesia yang diabadikan untuk kesejahteraan sosial yang adil bagi seluruh rakyat Indonesia. Dalam konteks struktur keadilan sosial ini, kehidupan masyarakat yang terorganisasi sebagai ciri masyarakat yang modern dan demokratis menjadi substansi nilai-nilai yang harus dijadikan pegangan dalam praktik kebijakan keadilan sosial yang tidak lain merupakan kebijakan-kebijakan yang berdampak nyata pada upaya mengatasi jurang kemiskinan dan menurunkan gejala ketimpangan sosial serta ekonomi dalam kehidupan bersama di Indonesia.. 


\section{DAFTAR PUSTAKA}

Buku

Asshiddiqie, Jimly. 1994. Gagasan Kedaulatan Rakyat dalam Konstitusi dan Pelaksanaannya di Indonesia. Jakarta: Ichtiar Baru-van Hoeve

Atmadja, D. G. and I. N. Putu. B . 2018. Teori-Teori Hukum. Malang: Setara Pres.

Crane, Laurence dkk. 2011. Introduktion to Risk Management, Second Edition. US: Extention Risk Management Education and Risk Management Agency.

Garner, Bryan A. 2004. Black’s Law Dictionary - Eight Edition. USA: West, a Thomson Business.

Hidayat, Nur. 2015. Corporate Tax Risk Management: Manajemen Risiko Perpajakan Perusahaan. Jakarta: PT Elex Media Komputindo

Kairupan, David. 2013. Aspek Hukum Penanaman Modal Asing Di Indonesia. Jakarta: Kencana Media Group.

La Ode Muhammad Elwan, S. and A. Pramusinto. 2011. Implementasi Perda Kota Kendari No. 15

Tahun 2003 Tentang Partisipasi Masyarakat Dalam Perumusan Kebijakan Daerah Pada Penyusunan Anggaran Pendapatan Belanja Daerah Tahun 2010. Yogyakarta: Universitas Gadjah Mada.

Sentosa, Sembiring. 2010. Hukum Investasi. Bandung: CV Nuansa Aulia.

Suharto, E. 2008. Kebijakan Sosial sebagai Kebijakan Publik. Bandung: ALFABETA.

Zvi Bodie, Alex Kane, and Alan J. Marcus. 2019. Dasar-Dasar Investasi, Jakarta: Salemba Empat.

Peraturan Perundang-undangan

Undang-Undang Nomor 19 Tahun 2003. Badan Usaha Milik Negara. Lembaran Negara Republik Indonesia Nomor 70 Tahun 2003, Tambahan Lembaran Negara Republik Indonesia Nomor 4297. Jakarta.

Jurnal Ilmiah

Bismar Nasution. Pembaharuan Hukum Menuju Perekonomian Global: Perspektif Kawasan ekonomi Khusus. Makalah Disampaikan Dalam Seminar Nasional "Pembaharuan Hukum Menuju Perekonomian Global’.Universitas Prima Indonesia, Tanggal 15 Desember 2011, hal. 5 
Merdiansa paputungan, "Diskusi kewenangan Audit BPK terhadap Keuangan BUMN (Perseroan) Pasca-Putusan MK Nomor 62/PUU-XI/2013”, Mimbar Hukum, Volume 29, Nomor 3, Fakultas Hukum Universitas Gajah Mada, 2017, hlm.438

Marlinah, Lili. 2020. Peluang dan Tantangan UMKM Dalam Upaya Memperkuat Perekonomian Nasional Tahun 2020 Ditengah Pandemi Covid 19. Jurnal Ekonomi, 22, 118-121

Websites

https://kek.go.id/kawasan/Mandalika.html, diakses 20 April 2021

http://www.negarahukum.com/hukum/risiko.html, diunduh tanggal 20 April 2021. 